\title{
Prevention StRategies: NeW DEPARTURES - A UNION PERSPECTIVE
}

\author{
Ross Wilson *
}

This paper provides a trade union perspective on the changes to the New Zealand statutory framework for injury prevention during the 1990s, in the context of the political, social and economic environment of the time, and the measures taken since the election of the Labour-led government in 1999 to legislate employee rights, foster applied injury programmes on an industry basis, and to acknowledge injury prevention as a community responsibility. It concludes that these "new departures" are essentially those identified by the Woodhouse Royal Commission in 1967.

\section{INTRODUCTION}

It is a measure of the foresight and wisdom of the 1967 Royal Commission of Inquiry that it is possible, 36 years later, to be able to refer back to its remarkable Report ${ }^{1}$ for pointers as to what are still unrealised "new directions" for injury prevention in New Zealand.

Justice Woodhouse's view of accidents as complex events, although consistent with a Scandinavian approach, was well advanced of the New Zealand thinking of the time, or the subsequent decades.

But if this approach was hard to grasp 35 years ago, it is certainly more readily understood today in a world where there is daily debate about the disabling effects of poorly designed work stations, poorly structured work organisation, the health effects of toxic exposures both in the workplace and the general environment, and the unknown effects of genetically modified foods.

The old tools of common law deterrence and market-based financial incentives belong to a much simpler world. However, this rather obvious reality did not prevent the neo-liberals in New Zealand trying to apply their old ideology in the 1990s. As Richard Gaskins has noted: ${ }^{2}$

* $\quad$ President, New Zealand Council of Trade Unions.

1 New Zealand Royal Commission of Inquiry into Compensation for Personal Injury Compensation for Personal Injury in New Zealand: Report of the Royal Commission of Inquiry (Government Printer, Wellington, 1967) ["Woodhouse Report"]. 
... For economic reasons the notion still exists that accidents can be neatly classified as to cause, and that every accident is the unique financial obligation of a single agent. The same logic leads to the further conclusion that where there is no proven injury there can be no responsibility for safety.

It is therefore useful to briefly revisit some of the key developments in the workplace injury prevention and health protection framework over the years since the Woodhouse Report, as a precursor to identifying some $21^{\text {st }}$ century "new directions".

\section{THE WOODHOUSE REPORT}

One of the key findings of the Woodhouse Commission, of course, was the rejection of the Shibboleth of the common law supporters, namely that the common law action had a deterrent effect in preventing accidents. The Commission could find no evidence to support the deterrent effect theory and noted that: "[i]f conscience, safety education, enforcement by inspection, and selfinterest all fail, then the sanctions of the criminal law still remain, and in our view at this point they should be applied."3

The Woodhouse Commission made two other key findings which are of interest given the subsequent history of the ACC scheme and the New Zealand legislative framework:

(1) It rejected merit or experience rating of employer levies and concluded that there was "no evidence here or overseas which shows that the process has any significant effect in the interests of safety."4 In fact it noted that North American evidence showed that it could have a contrary effect by encouraging a "tendency to withhold reports of accidents or to contest claims in order to produce a low accident ratio." 5

(2) It specifically endorsed the Swedish approach of "active co-operation between management and employee and in a wider sense between the trade unions and employers"6 and noted that the Swedish employer and trade union confederations worked on the principle that: ${ }^{7}$

... Not even the most elaborate safety legislation can give the desired results unless it is supported by active collaboration between employers and employees. Organised, voluntary

2 Richard Gaskins "Rebuilding ACC: An International View" in Rebuilding ACC Beyond 2000 (Conference Papers, New Zealand Council of Trade Unions, October 1999).

3 Woodhouse Report, above n 1, para 91.

4 Woodhouse Report, above n 1, para 336.

5 Woodhouse Report, above n 1, para 336.

6 Woodhouse Report, above n 1, para 337.

7 Woodhouse Report, above n 1, para 337. 
co-operation between the firm and its employees, supported and promoted by the central

organizations, fosters a sense of responsibility and interest in safety.

The Woodhouse Commission recommended as "a matter of prime importance that the proposed compensation system should be organised to take an active and coordinating role in the promotion of safety in all the different areas where accidents can occur." 8

\section{THE LAW COMMISSION REVIEW}

The Woodhouse Commission recommendation was heeded and the Accident Compensation Act 1982 identified that it was "a matter of prime importance for the Corporation to take an active and coordinating role in the promotion of safety." 9

But in practice it was accorded a low priority. ${ }^{10}$ In its 1988 Report, the Law Commission:

(1) Recommended the need for a Minister to be appointed to co-ordinate the activity of government agencies and with responsibility for the promotion of safety and the prevention of accidents of all kinds. ${ }^{11}$

(2) Concluded (as the Woodhouse Commission had) that there was no international evidence to support experience-rating of premiums, but acknowledged that there was a place for financial incentives and recommended that consideration be given to adopting the Canadian model of imposing penalties by reference to observed conditions. ${ }^{12}$

(3) Noted the work of the Advisory Council on Occupational Safety and Health (ACOSH) and evidence that worker participation can dramatically improve safety performance, and that a voluntary Department of Labour code on elected health and safety representatives and committees had been promoted by ACOSH. ${ }^{13}$

\section{CHANGES TO WORKPLACE HEALTH AND SAFETY LAWS}

New Zealand has followed the British tradition of minimum health and safety standards prescribed by quasi-criminal law and enforced by a Government inspectorate. Union involvement in workplace health and safety has been achieved only by agreement with employers.

8 Woodhouse Report, above n 1, para 318.

9 Accident Compensation Act 1982, s 35(1).

10 New Zealand Law Commission Personal Injury: Prevention and Recovery (Report on the Accident Compensation Scheme) (NZLC R4, Wellington, 1988) 23.

11 New Zealand Law Commission, above n 10, 32.

12 New Zealand Law Commission, above n 10, 39.

13 New Zealand Law Commission, above n 10, 28. 
The Fourth Labour Government introduced a new Occupational Safety and Health (OSH) Bill into Parliament in 1990 providing for a general duty and performance standards-based system. This was to be enforced through the law by an OSH inspectorate, but also provided for elected health and safety representatives following the influence from Scandinavia (which has also been reflected in the legislation in the United Kingdom and Australia). It was not passed before the Government was defeated in the general election that year.

However, consistent with the labour market deregulation introduced in the Employment Contracts Act 1991, the newly elected National Government removed the provisions relating to elected health and safety representatives. Its view was that health and safety should be managed by the employer, to the exclusion of employees or their representatives if the employer thought fit.

What this has meant is that, for the past 10 years, the Health and Safety in Employment Act 1992 has provided a general duty legislative framework, supplemented by a limited number of codes of practice and guidelines and enforced by a seriously under-resourced inspectorate. However, notably absent have been any of the worker rights or participation systems, such as the elected health and safety representatives, which have been a feature of the United Kingdom model since the Robens Report ${ }^{14}$ in the 1970s which, in turn, was heavily influenced by the Scandinavian models.

In effect, our legislation has been like a two-legged stool. The employers had a clear general duty, and the inspectorate had a clear enforcement role, but employees and their unions were denied any statutory role. This third leg was an essential part of the Robens and Scandinavian models.

\section{THE ACCIDENT COMPENSATION SCHEME}

The Accident Insurance Act 1998 created an "accident injury insurance market" for work accidents. The intention was that the "market" would determine prevention policies, as ultimately private contracts would dictate the levels of compensation. ${ }^{15}$

The policy approach rested entirely on the belief that employers would respond to the prospect of reduced future premiums by investing in injury prevention and health protection programmes. This approach displayed either a breathtaking naivety or a disturbing ignorance of the realities of the modern workplace and its participants. In simplistic terms it was re-introducing a very weak form of deterrence. It failed to recognise that in modern workplaces the causes of accidents and occupational disease are frequently complex and multifarious.

14 Report of the Committee on Safety and Health at Work (1972) Cmnd 5034.

15 Hon Murray McCully and Deborah Morris "Budget 1998" (14 May 1998) Press Release. 
In doing so the Government of the day, strongly supported by private insurance companies, turned its back on the unrealised potential of the Accident Compensation Scheme. This was that a scheme founded on the principle of "community responsibility" has a unique potential, in the modern environment of increased causative complexity, to provide a coordinated public response to societal risk. In this respect, as in so many other policy areas, public policy on injury prevention went back 30 years.

\section{SAFETY IN THE "DEREGULATED LABOUR MARKET"}

Although little research evidence is available about the impact on New Zealand workplace health and safety of the neo-liberal experiment of the 1990s, there is a general acknowledgement that it has had an adverse effect, particularly as a result of the deregulation of the labour market and the legislative health and safety framework.

A published study comparing work related fatal injuries in United States, Australia, and New Zealand revealed that New Zealand had the highest average annual rate (4.9/100,000), Australia an intermediate rate $(3.8 / 100,000)$ and the United States the lowest rate $(3.2 / 100,000)$ although some of the difference between countries was accounted for by differences in industry distribution. ${ }^{16}$

Another study has shown that, although occupational related fatality rate reductions of between 60 per cent to 70 per cent have been achieved over the past two decades in Sweden, Japan, Germany and the United States, the New Zealand fatality rate reduction over the past two decades has, at best, been 30 per cent. ${ }^{17}$

The last decade has seen a growth in precarious employment: shiftwork and nightwork, selfemployment, part-time jobs, multiple job holding, home work, and casual and temporary employment (increasingly through labour-hire companies). At the same time there has been an increase in working hours and intensity of work for some sections of the workforce.

The effects of precarious work have been illustrated in a recent qualitative study of the impact of work hours on 30 families commissioned by the New Zealand Council of Trade Unions. ${ }^{18}$

A recent review of 93 research studies covering a range of industries in 11 countries and employing a number of methodologies has shown that the growth of these types of work

16 A-M Feyer and others "Comparison of Work Related Fatal Injuries in the United States, Australia and New Zealand" (2001) 7 Injury Prevention 22-28.

17 A-M Feyer and others Work-Related Fatal Injuries in New Zealand 1984-1994 (New Zealand Environmental and Occupational Health Research Centre and Injury Prevention Research Unit, 1999).

18 New Zealand Council of Trade Unions Thirty Families: Interim Report of the Thirty Families Project: The Impact of Work Hours on New Zealand Workers and Their Families $2002<$ http://www.union.org.nz/> (last accessed 15 November 2004). 
arrangements are having adverse effects on workers' health and safety. ${ }^{19}$ Of the 93 studies, 76 found that precarious employment was associated with a measurable deterioration in occupational safety and health. ${ }^{20}$

The experience in New Zealand accords with the broad findings common to those studies:

(1) First, precarious employment is often associated with economic pressures or changes to payment and reward systems that endanger health. These include competitive tendering and consequent "corner-cutting" by subcontractors, the outsourcing of dangerous tasks, payment by results and low pay, work intensification and overload, long hours of work, and the limited resources that small businesses can devote to complying with occupational health and safety legislation.

(2) Second, precarious employment can be associated with dangerous forms of work disorganisation. Ensuring adequate training of temporary or labour hire workers is difficult, especially where the workforce is young and inexperienced or where there is a high level of labour turnover. Outsourcing and labour hire contracting means the introduction of "strangers" to the workplace, disruption of informal flows of safety knowledge and communication, and an increase in complexity and ambiguity in rules and procedures. Downsizing can result in a loss of knowledge with the loss of older and more experienced workers and resulting multi-tasking may result in additional risks if workers are not suitably retrained. People doing precarious work are often in a weak position to raise or complain about occupation health and safety issues, particularly in a non-union environment.

(3) Third, the occupational health and safety regulatory framework is designed and implemented to predominantly deal with permanent employees in large workplaces. On multi-employer work-sites, such as construction sites, complex webs of legal and management responsibility and control increase risk. To compound this, changes to labour legislation weakened minimum standards and union input resulting in unionised workers working excessive hours at low rates of pay.

In New Zealand the employment and occupational health and safety laws have had a negative effect on worker and union involvement in occupational safety and health standard setting and management.

19 M Quinlan, C Mayhew and P Bohle "The Global Expansion of Precarious Employment, Work Disorganisation, and Consequences for Occupational Health: A Review of Recent Research" (2001) 31 Int'l J Health Services 335 .

20 Quinlan, Mayheur and Bohle, above n 19, 335. 
The Employment Contracts Act 1991 severely limited union access to workplaces without employer consent. Similarly the Health and Safety in Employment Act 1992 contained no mandatory employee participatory mechanisms.

Collective bargaining was almost halved in the 1990s, enterprise documents and individual employment contracts were almost universal, and union density fell from 35.4 per cent of the labour force in 1991 to 17 per cent by $1999 .{ }^{21}$

The result for occupational safety and health protection was:

(1) The widespread weakening of employee participation in occupational safety and health.

(2) A lessening of employee knowledge and awareness of health and safety issues.

(3) A weakening of union representation and bargaining on health and safety issues.

(4) An increasing unwillingness of workers to report workplace health and safety problems.

\section{EMPLOYMENT LAW REFORM 2000}

One of the first legislative measures by the Labour-Alliance Coalition Government elected in 1999 was the introduction of a new Employment Relations Act 2000 firmly based on the International Labour Organisation (ILO) Conventions 87 and 98. These ILO core conventions recognise freedom of association and the promotion by the State of collective bargaining as guaranteed human rights. The Act also allows union access to the workplace for any purpose.

As a result, a social partnership approach is developing and new and co-operative working relationships are developing between government, employers and unions at national, industry and workplace level.

The basis for these new relationships is the Employment Relations Act 2000, with its requirements for good faith working relationships. The re-emerging union movement and collective bargaining form the organisational base on which to rebuild workplace health and safety standards at a workplace and industry level.

It is anticipated that collective agreements may develop as a workplace framework within which employers and employees can develop injury prevention and health protection programmes, as well as the more traditional conditions of employment.

However, collective bargaining is only part of the solution. It has been recognised by the Government, and the Council of Trade Unions, that many groups of workers will be beyond the coverage of collective bargaining, particularly in the short term.

21 Robyn May, Pat Walsh and Peter Kiely Employment Agreements: Bargaining Trends and Employment Law Update 2003/2004 (Industrial Relations Centre, Victoria University of Wellington, Wellington, 2004). 
For this reason, following the European model, a statutory minimum code of employment conditions and rights is progressively being put in place for the benefit of those workers outside the unionised collective bargaining sector, many of whom are more vulnerable groups of workers in precarious employment. This has included improved minimum wage rates, and an upgrading of annual holiday and special leave entitlements.

It is perhaps worthy of comment that more than a century ago (in labour market conditions with some striking similarities with the labour market of today) many industrialised countries identified working conditions as exploitative and unhealthy. At that time unions and political allies were able to achieve legislative intervention with factories legislation which addressed hours of work and other minimum labour standard issues.

Today we are again seeing a growing awareness in our country that the current issues of working conditions, including precarious employment and associated health and safety issues, need to be addressed.

\section{OCCUPATIONAL HEALTH AND SAFETY}

One of the most important minimum code protections is the right to a safe and healthy workplace. The Government has recently overhauled New Zealand's occupational safety and health legislation.

The Council of Trade Unions strongly believes that the Government has a responsibility to provide an effective occupational safety and health statutory framework at national, industry, and enterprise levels.

At the national level there should be a tri-partite process which determines acceptable minimum standards of safety. Having established national minimum standards these should be embodied in understandable legislation, regulations and codes of practice which are well publicised. These minimum standards should be rigorously enforced by an inspectorate with substantial penalties for breaches.

At industry level legislation should encourage the development of processes and programmes which aim for best practice in health and safety. These occupational safety and health strategies should be integrated with quality management and worker participation so that work and workplace design, training and protection of the safety and health of workers can be addressed on an industry basis.

At workplace level there should be legislative recognition of the workers' rights to know (about potential hazards they face at work), the right to participate (in decisions affecting their safety and health at work), and the right to refuse dangerous work. While the critical importance of management commitment to health and safety is acknowledged, the involvement of workers is both a valuable contribution to the solution of health and safety problems and an important expression of industrial democracy. 
International experience has shown that the best prevention strategies involve the people at risk, the employees, developing and maintaining their own safe systems of work.

The 2003 amendments to the Health and Safety in Employment Act 1992:

(1) Place a new general legal duty on all employers to ensure that all employees have the opportunity to be effectively involved in health and safety processes. ${ }^{22}$

(2) Give all workers the right to elect health and safety representatives in their workplace with statutory or agreed roles as part of worker participation arrangements. Unless otherwise agreed health and safety representatives will have an annual right to two days training leave and the power to serve hazard notices on employers. ${ }^{23}$

(3) Provide all workers with a statutory right to refuse dangerous work (which is arguably an obligation under the section 19 duty on all workers to take all practicable steps to protect their own health and safety and the health and safety of others). ${ }^{24}$

(4) And for those employers who understand (and respond to) nothing else, the amendments increase the maximum fine from $\$ 100,000$ to $\$ 500,000 .^{25}$

The Council of Trade Unions began preparing for this health and safety representative system in early 2002. We developed a two-day training course and went to the Accident Compensation Corporation for funding assistance.

Eventually we ended up negotiating a joint venture agreement with the ACC for an organisation which would develop and deliver high quality training.

We succeeded in developing the joint venture because we were able to demonstrate:

(1) That international research shows that worker participation is an essential ingredient of effective injury prevention and health protection and that well-organised union workplaces are twice as safe as non-union workplaces.

(2) That we can deliver training with credibility, and at a reasonable cost - a fraction of the cost of employer and other private providers.

The challenge for us as a union movement is to organise and build the health and safety representative system in all New Zealand workplaces, with proper training and resources, so that unions are at the cutting edge of best practice health and safety in the workplace.

22 Health and Safety in Employment Act 1992, s 6.

23 Health and Safety in Employment Act 1992, Part 2A.

24 Health and Safety in Employment Act 1992, ss 19 and 28A.

25 Health and Safety in Employment Act 1992, ss 49-50. 
And, that is why we have:

(1) Developed the joint venture training organisation in partnership with ACC, not only to deliver the current two-day base course, but also to deliver a hierarchy of courses which will build workplace knowledge and expertise over the years ahead.

(2) Built a new health and safety representatives' website through which representatives can obtain and exchange information.

(3) Plans to organise regular regional meetings for health and safety representatives as an educational and networking opportunity.

We have set a target of 5000 elected and trained representatives in the first 12 months to 5 May 2004. We already have 4000 elected, and have more than 2000 trained or scheduled for training sessions.

Our commitment to unions is that, if they organise the elections and put the names and details of the representatives into our specially developed national computer database, we will organise training sessions anywhere in New Zealand where there are 20 or more representatives needing training.

The key challenges for unions are threefold:

(1) First, we must change the perception, where it still exists, that health and safety is a specialist area which should be left to a few "experts".

(2) Secondly, having accepted that health and safety is a key focus for organising, the challenge is to develop effective and strategic organising strategies which include health and safety as a key issue, and to do so at both an enterprise and industry level.

Those strategies should take account of the potential to work with Occupational Safety and Health and ACC. The health and safety representatives' work, including the hazard notice power, is complementary to the Occupational Safety and Health Inspector's enforcement work. Similarly the ACC Safer Industries programmes include the opportunity for participation by lead health and safety representatives in the industry standard setting processes.

(3) Thirdly, there is the challenge to make the fundamental link between unsafe systems of work, which cause accidents and occupational diseases, and the potential for collective bargaining to improve those systems of work thereby preventing accidents and disease.

Just as the laws and practices of the 1980s and 1990s allowed, and assisted, the deterioration of systems of work, so can the rights that we now have under the new Employment Relations Act 2000 and the Health and Safety in Employment Act 1992 assist us to rebuild safe systems and conditions of work, and improve the life/death balance in New Zealand workplaces. 
Health and safety is an integral part of union work, and that must include working with Government and employers in tripartite and bipartite injury prevention initiatives. All union members expect their unions to be working to improve their conditions of employment, and nothing is more fundamental than organising to protect their lives, limbs and good health.

With a core vanguard of 4000 health and safety representatives elected already, and the best training programme and trainers in the country, we are already well on the road to achieving our vision.

\section{CRIMINAL LAW AS AN INJURY PREVENTION TOOL}

While the Council of Trade Unions warmly welcomes the employee rights and participation provisions in the new Act, ${ }^{26}$ we have concerns about the continued criminal law structure of the enforcement process. It is therefore appropriate to question whether enforcement of workplace health and safety standards though the criminal law (that is, the Health and Safety in Employment Act 1992) is the best policy option, particularly as a preventive measure.

The policy approach of the Governments of the 1990s was that the "signals" that fines under the Health and Safety in Employment Act 1992 provide, together with the incentives provided by ACC experience rating of premiums, would ensure that employers pursued accident prevention through risk management techniques. The experience rating system added penalty loadings on employers' premiums if the cost of claims from the employer was above the average of other employers in the same industry classification.

In practice, experience rating proved ineffective as an injury prevention tool and has been abolished, and the "signals" from the Health and Safety in Employment Act 1992 have, because of relatively low fines, been rather $\operatorname{dim}$.

It is entirely appropriate, given the strong Anglo-Saxon influence in our legal system, that there should be minimum standards enforced through the criminal law. There is considerable support for not only increasing the maximum fines, but also for introducing corporate manslaughter for serious cases.

However, the Council of Trade Unions has been advocating the view that an effective administrative penalty system, perhaps modelled on that of British Columbia, can be developed to supplement the system of criminal prosecution.

There is cogent evidence from around the world that administrative penalty systems can be effective in that they impose significant penalties directly on identified hazards and unsafe systems of work. ${ }^{27}$ Such a system has operated effectively in British Columbia since the 1970s. It would

26 Health and Safety in Employment Act 1992.

27 Kathleen Rest and Nicholas Ashford Occupational Safety and Health in British Columbia: An Administrative Inventory (Workers Compensation Board of British Columbia, Richmond, 1992). 
appear that some of the significant reasons for the effectiveness of such systems as an injury prevention tool are that:

(1) Penalties can be imposed on hazards identified by inspectors as an incentive to eliminate the hazard. In New Zealand more than 90 per cent of Health and Safety in Employment Act 1992 prosecutions take place as a consequence of a serious accident. The administrative penalty system thus encourages Occupational Safety and Health Inspectors to look at the system of work. Also, it uses the penalty power as a preventative rather than an ex post facto punitive measure.

(2) The maximum penalties imposed can be substantial and can be increased for continuing non-compliance.

(3) The system is relatively inexpensive (compared to criminal prosecution) yet natural justice is preserved by providing a right of appeal to a legal forum against the imposition of a penalty.

(4) It moves away from breaches of workplace health and safety standards as breaches of criminal law and toward an administrative system which directly imposes penalties on identified hazards or breaches of standards.

(5) It also enables a proper focus on occupational health hazards that often tend to be ignored in a criminal prosecution system because of long latency periods for many occupational diseases which make it difficult to prove a causal link back to a specific hazard.

The real challenge is to work together within the government framework and the incentives it provides, to move beyond minimum standards and to achieve best practice in the health and safety protection of all workers.

The criminal law-based health and safety framework is no substitute for properly researched and applied injury prevention and health protection programmes.

\section{COMMUNITY RESPONSIBILITY AND NATIONAL INJURY PREVENTION STRATEGIES}

It is therefore fortuitous that one of the early legislative steps also taken by the LabourAlliance Government was the abolition of the private insurance market for workplace accident insurance and the re-establishment of the national single public fund accident injury scheme with strong responsibilities for injury prevention.

The Council of Trade Unions is working with ACC and employers in several industries to develop industry-based injury prevention and health protection organisations. The objective is to ensure that the new systems of employee participation (through employee health and safety representatives) are taken to industry level. It is our objective to draw on the experience of other 
countries and develop tripartite industry associations which will analyse industry hazards and develop and apply solutions through best practice programmes.

But the ultimate opportunity is to realise the full potential of our no-fault accident compensation scheme by addressing injury prevention on a society wide basis, as part of community responsibility. As a modern union movement in New Zealand, our concerns are not confined to the parameters of the workplace. Our union members reflect a cross section of the workforce, all of whom are exposed to hazards and risks 24 hours a day, seven days a week, in their homes, on the roads, and in their leisure activities, as well as in the workplace.

We are currently working with Government and other social partners on the implementation of a National Injury Prevention Strategy ${ }^{28}$ which will provide a framework for addressing injury prevention on a society wide basis.

This requires a culture change in New Zealand and a recognition that the toll of injury and death in all areas of activity can be drastically reduced with properly developed and applied strategies which recognise that the social and monetary cost to society of these is unacceptable. The principles and priorities of the National Injury Prevention Strategy are now being developed into more focused strategies. This includes a national Workplace Health and Safety Strategy, the development of which is being led by the Department of Labour and a tripartite reference group.

\section{THE WOODHOUSE VISION: NEW DEPARTURES}

It is also appropriate that we acknowledge that the "new departures" we are developing in injury prevention and health protection are essentially the measures originally recommended in the 1967 Woodhouse Report. These are:

(1) "Active co-operation" between employers, employees and unions.

(2) Promotion of safety as a priority by ACC.

(3) Penalties on observed conditions rather than experience rating.

(4) Underpinning of the criminal law.

It has taken a long time to get there, and we have been down some blind alleys in the process, but there is increasing confidence that we have now got the policy settings right. The challenge is to use them to make New Zealand a safer place to live and work.

So today, as we look forward to a new era of effective injury prevention, we should salute the perceptive wisdom and foresight of Sir Owen Woodhouse who pointed the way so clearly 36 years ago.

28 Hon Ruth Dyson New Zealand Injury Prevention Strategy (June 2003) <www.nzips.govt.nz> (last accessed 15 November 2004). 
